\title{
Sensitivity analysis in a simulated auto thermal Natural Gas reforming process
}

\author{
H. Baloğlu and G. Nasün-Saygılı* \\ Department of Chemical Engineering, \\ Istanbul Technical University, \\ 34469 Maslak, Istanbul, Turkey \\ E-mail: nasun@itu.edu.tr \\ *Corresponding author
}

\begin{abstract}
Auto Thermal natural gas Reforming (ATR) is one of the mostly used conventional hydrogen generation technologies by the highly developed countries. ATR reactors do not need any direct or indirect heat exchanger, and that is why they are more compact and so preferable than the other reformers. In this study, a process including reformers, carbon dioxide sequestration and a cryogenic separation sub-process is simulated for a defined standardised base case feed streams. Operating conditions of the main equipments, the inlet and the outlet stream properties and compositions, general mass balances and also the possible solid carbon dioxide formation conditions of the process streams are estimated to show the consistency of the process for the base case. In the sensitivity study, the effects of $\mathrm{O}_{2} / \mathrm{C}$ and $\mathrm{H}_{2} \mathrm{O} / \mathrm{C}$ feed stream mass ratios and the capacity of the process on flow rates of the process stream compositions, e.g. hydrogen, carbon monoxide, carbon dioxide, residual water and methane, etc. are investigated. In addition, the effects of reforming and the shift reactor temperatures on the total hydrogen generation are determined. Consequently, the possible steam generation conditions and hydrogen, carbon dioxide separation units' operating conditions are examined for the simulated process, considering the base case defined.
\end{abstract}

Keywords: Auto Thermal Reforming; ATR; cryogenic separation; $\mathrm{H}_{2} \mathrm{O} / \mathrm{C}$; $\mathrm{O}_{2} / \mathrm{C}$; Partial Oxidation of Methane; POX; process simulation; sensitivity analysis; Steam-Methane Reforming; SMR; Water-Gas Shift; WGS.

Reference to this paper should be made as follows: Baloğlu, H. and Nasün-Saygıll, G. (2008) 'Sensitivity analysis in a simulated auto thermal Natural Gas reforming process', Int. J. Alternative Propulsion, Vol. 2, No. 1, pp.50-71.

Biographical notes: Halit Baloglu is a Researcher in TUBITAK and a PhD student in the Chemical Engineering Department at the Istanbul Technical University. His research areas of interest include computer aided design and boron processes. He made technical presentations of his works at international conferences.

Gulhayat Nasun-Sayg11 is a Professor of the Chemical Engineering Department, Istanbul Technical University. She teaches undergraduate and graduate courses as Transport Phenomena, Unit Operations, Stagewise Operations, Fluid Dynamics, CAD/CAM and CFD. Her research areas of interest include modelling and simulation, computer aided design of chemical plants, removal of hazardous materials from wastewaters, mineral processing. She has authored technical papers in various journals and made numerous technical presentations of her work in these fields at international conferences.

Copyright (C) 2008 Inderscience Enterprises Ltd. 


\section{Nomenclature}

Act. Pow. Actual Power

ATR Auto Thermal natural gas Reforming

CHD Calculated Heat Duty

FTR Fired Tubular Reactor used reforming

HTS High Temperature Shift

LTS Low Temperature Shift

Lv Liquid Volume

MEA Monoethanolamine

MER Methanation Equilibrium Reactor

NG Natural Gas

PFD Process Flow Diagram

POX Partial Oxidation of methane

Press. Pressure

PSA Pressure Swing Adsorption

R\&D Research and Development

SMR Steam-Methane Reforming

std $\quad$ Standard

Temp. Temperature

Th. Pow. Theoretical Power

Vv Vapor Volume

w/w Weight over weight, $\mathrm{kg} / \mathrm{kg}$

WGS Water-Gas Shift equilibrium reaction

\section{Introduction}

Hydrogen generation technologies are attracting attention recently basically because of global warming and cease of fossil fuels. These facts direct researchers to find the effective use of the fuels left. Hydrogen is one of the defined renewable energy sources that are safe, cost effective, multi-directionally and environmentally favourable. It is the lightest element of all and has a calorific value of nearly 3.2 times the petroleum. The impelling factor of liquid and gas hydrogen engines is $100 \%$ while LPG engines' $62 \%$ and gasoline engines' $75 \%$ also. Two hundred times less $\mathrm{NO}_{\mathrm{x}}$ release from Liquid hydrogen and Gaseous hydrogen engines in addition, according to the fossil fuel engines 
also directs authorities to encourage the researchers nowadays even in developing countries.

In literature, a case study was done by a simulation of a general SMR plant to verify the advantages of a single step $\mathrm{H}_{2}$ generation process. The simulations were based on chemical equilibrium having mainly the same reaction stages as in this study, where the excess water was removed by condensation and the $\mathrm{CO}_{2}$ was removed by a Monoethanolamine (MEA) cycle. Aspen-Plus were the preferred simulation programme for that study and the main results were summarised (Ortiz, Balasubramanian and Harrison, 2001). In another study, a FTR and ATR process is modelled to determine the possible maximum electricity and hydrogen generation with optimum operating conditions (Consonni and Vigano, 2005). However, there is no study on sensitivity analysis to determine the aspects of a SMR or an ATR process in literature. That is why this sensitivity study is done to give attitudes in building large scale hydrogen reforming plants. In addition, another study done by collecting data from an existing hydrogen generation plant, also some of the data used in this study, as the cheapest way to generate hydrogen is revealed recently that can give other points of view to reforming processes (Contadini et al., 2000).

An ATR process mainly consists of three stages, main reforming, $\mathrm{CO}_{2}$ sequestration and hydrogen purification. Reforming stage includes one reforming, one or two shift reactors and several heat exchangers. An ATR reactor as stated does not need a direct or indirect heat exchanger to drive the reforming reaction. Heat exchangers are used to maintain the feed stream requirements fed to the reactors by reactor product stream. Second stage is the carbon dioxide sequestration with a flash and component separator unit and the last stage is the hydrogen purification stage as called in this study as cryogenic subprocess. Both $\mathrm{CO}_{2}$ and $\mathrm{H}_{2}$ separations are managed by cryogenic separation principles. Further detailed operating conditions are in the definition of the simulated process.

After validating the defined ATR process for the base case, it is used for the sensitivity analysis. The summary of the results, general design parameters and the operating conditions of the validated base case study were also presented in an international conference (Baloğlu and Nasun-Saygıl1, 2005). By this analysis, the effects of $\mathrm{O}_{2} / \mathrm{C}$ and $\mathrm{H}_{2} \mathrm{O} / \mathrm{C}$ ratios, capacity of the process on output stream compositions are determined. Besides, effects of reforming and the shift reactor temperatures, hydrogen and carbon dioxide separation operating conditions are investigated with appropriate assumptions.

An additional study is done also to utilise the heat duty of one sided heat exchangers that are used to cool the product streams.

\section{Definition of the process}

Here, the feed stream properties and ranges used in sensitivity analysis and in general process, ATR principle defined in the simulation and the cryogenic separation process used is specified in details. It is assumed for the simulated process that input Natural Gas (NG) does not include $\mathrm{H}_{2} \mathrm{~S}$ or $\mathrm{NO}_{\mathrm{x}}$ gases. It is supposed to be removed before fed to the process by a chemical adsorption unit. Another assumption is that for the simulated reforming process the $\mathrm{NO}_{\mathrm{x}}$ and $\mathrm{SO}_{\mathrm{x}}$ formation is so less to be neglected. 


\subsection{Feed streams and ratios}

The simulated process has a NG, a steam and an air feed inlet streams. The NG composition by moles is generally $98.70 \%$ methane (within the other hydrocarbons), $0.80 \%$ nitrogen and $0.50 \%$ carbon dioxide (Spath and Mann, 2001). NG incoming to the plant is at about 10-21 bar pressure (Contadini et al., 2000). Second stream is the air stream that has a composition by volume of $78.08 \%$ nitrogen, $20.95 \%$ oxygen and the rest is water vapour at sea level atmospheric pressure. The third stream is the water steam (Manahan, 2000). It comes to the plant generally at about 24.1-26.5 bar pressure and about $265-280{ }^{\circ} \mathrm{C}$ temperature. These average industrial literature values stated here are considered while determining the feed stream compositions and properties in the simulation and of course in the sensitivity analysis. The properties of the inlet and the outlet stream properties for the simulated base case and for the sensitivity analysis are shown in Tables 1 and 2, respectively.

Table 1 Inlet stream compositions and properties of the process

\begin{tabular}{lrrrr}
\hline Stream no & \multicolumn{1}{c}{2} & \multicolumn{1}{c}{3} & 33 \\
\hline Stream name & & & & \\
Temperature $\left({ }^{\circ} \mathrm{C}\right)$ & $25.00^{*}$ & $25.00^{*}$ & $265.00^{*}$ & $25.00^{*}$ \\
Pressure (bar) & $1.00^{*}$ & $10.00^{*}$ & $25.00^{*}$ & $1.00^{*}$ \\
Enthalpy (MJ hour $\left.{ }^{-1}\right)$ & 713.33 & $-23,467$ & $-1.43 \times 10^{5}$ & $-1.65 \times 10^{5}$ \\
Vapour mole fraction & 1.00 & 1.00 & 1.00 & 0.00 \\
Total $\left(\mathrm{kmol} \mathrm{hour}^{-1}\right)$ & 191.61 & 307.15 & 607.44 & 577.07 \\
Total $\left(\mathrm{kg} \mathrm{hour}^{-1}\right)$ & $5,481.35$ & $5,000.00$ & $10,943.05$ & $10,395.90$ \\
Total standard $\mathrm{Lv}\left(\mathrm{m}^{3}\right.$ hour $\left.^{-1}\right)$ & 6.36 & 16.38 & 10.95 & 10.40 \\
Total standard Vv $\left(\mathrm{m}^{3}\right.$ hour $\left.^{-1}\right)$ & $4,294.75$ & $6,884.39$ & $13,614.97$ & $12,934.22$ \\
Flow rates in $\left(\mathrm{kg} \mathrm{hour}^{-1}\right)$ & & & & $10,395.90$ \\
Water & 53.17 & 0.00 & $10,943.04$ & 0.00 \\
Methane & 0.00 & $4,863.57$ & 0.00 & 0.00 \\
Oxygen & $1,148.34$ & 0.00 & 0.00 & 0.00 \\
Nitrogen & $4,279.84$ & 68.83 & 0.00 & 0.00 \\
Carbon dioxide & 0.00 & 67.59 & 0.00 & 0.00 \\
Carbon monoxide & 0.00 & 0.00 & 0.00 & 0.00 \\
Hydrogen & 0.00 & 0.00 & 0.00 & \\
\hline
\end{tabular}

*Feed stream properties defined by user.

Table 2 Outlet stream compositions and properties of the process

\begin{tabular}{|c|c|c|c|c|c|c|}
\hline Stream no & 19 & $21^{a}$ & $30^{a}$ & 31 & 32 & 36 \\
\hline \multicolumn{7}{|l|}{ Stream name } \\
\hline Temperature $\left({ }^{\circ} \mathrm{C}\right)$ & 47.07 & 35.00 & -83.50 & -83.50 & -80.00 & 275.83 \\
\hline Pressure (bar) & 30.00 & 35.46 & 1.01 & 1.01 & 95.08 & 25.00 \\
\hline Enthalpy (MJ hour ${ }^{-1}$ ) & $-28,474$ & $-1.12 \times 10^{5}$ & $-3,372$ & $-2,697$ & $-1,631.3$ & $-1.36 \times 10^{5}$ \\
\hline Vapour mole fraction & 0.00 & 1.00 & 1.00 & 1.00 & 0.00 & 1.00 \\
\hline
\end{tabular}


Table 2 Outlet stream compositions and properties of the process (Continued)

\begin{tabular}{|c|c|c|c|c|c|c|}
\hline Stream no & 19 & $21^{a}$ & $30^{a}$ & 31 & 32 & 36 \\
\hline Total $\left(\mathrm{kmol}\right.$ hour $\left.^{-1}\right)$ & 100.16 & 282.73 & $1,095.38$ & 177.07 & 5.56 & 577.07 \\
\hline Total (kg hour $\left.{ }^{-1}\right)$ & $1,808.05$ & $12,442.74$ & $2,208.08$ & $4,865.97$ & 100.04 & $10,395.90$ \\
\hline $\begin{array}{l}\text { Total standard } \\
\operatorname{Lv}\left(\mathrm{m}^{3} \text { hour }^{-1}\right)\end{array}$ & 1.81 & 15.05 & 31.55 & 6.29 & 0.10 & 10.40 \\
\hline $\begin{array}{l}\text { Total standard } \\
\text { Vv }\left(\mathrm{m}^{3} \text { hour }^{-1}\right)\end{array}$ & $2,245.04$ & $6,336.90$ & $2,4551.57$ & $3,968.76$ & 124.66 & $12,934.22$ \\
\hline \multicolumn{7}{|c|}{ Flowrates in $\left(\mathrm{kg} \mathrm{hour}^{-1}\right)$} \\
\hline Water & $1,801.27$ & 0.00 & 0.00 & 0.20 & 99.90 & $10,395.90$ \\
\hline Methane & 0.01 & 0.00 & 0.00 & 126.33 & 0.01 & 0.00 \\
\hline Oxygen & 0.00 & 0.00 & 0.00 & 0.00 & 0.00 & 0.00 \\
\hline Nitrogen & 0.06 & 0.00 & 0.00 & $4,348.89$ & 0.09 & 0.00 \\
\hline Carbon dioxide & 6.65 & $12,442.74$ & 0.00 & 0.00 & 0.00 & 0.00 \\
\hline Carbon monoxide & 0.01 & 0.00 & 0.00 & 390.56 & 0.01 & 0.00 \\
\hline Hydrogen & 0.05 & 0.00 & $2,208.08$ & 0.00 & 0.02 & 0.00 \\
\hline
\end{tabular}

${ }^{a}$ Stream compositions are given for 1:1 separation (not actual separation properties and compositions).

\subsection{Auto Thermal Reforming}

The difference between the conventional steam methane reforming and the ATR is the partial oxidation reaction taking place in the main reforming reactor, Methanation Equilibrium Reactor (MER) simultaneously. This Partial Oxidation (POX) is an exothermic and one sided reaction that can be controlled to maintain the high reforming temperature for the reactor. This situation results in more compact and cheap reforming reactor designs and no need to integrate any direct or indirect heat exchangers (Ogden, 2001). Reactor temperature is adjusted with the oxygen or air amount fed to the reactor by controlling the POX kinetics (James, 2001). The main highly endothermic reforming reaction is given by the Equation (1).

$$
\mathrm{CH}_{4}+\mathrm{H}_{2} \mathrm{O} \leftrightarrow \mathrm{CO}+3 \mathrm{H}_{2} \text {. }
$$

The following reaction Equation (2), is possible to occur at the same time in MER also (Ogden, 2001).

$$
\mathrm{CH}_{4}+2 \mathrm{H}_{2} \mathrm{O} \leftrightarrow \mathrm{CO}+4 \mathrm{H}_{2} .
$$

One-sided exothermic POX utilised for heating of reformer is shown in Equation (3),

$$
\mathrm{CH}_{4}+\frac{1}{2} \mathrm{O}_{2} \rightarrow \mathrm{CO}+2 \mathrm{H}_{2}
$$

and the following reaction Equations (4) and (5), are also possible to occur in MER (Lee et al., 2004).

$$
\begin{aligned}
& \mathrm{CH}_{4}+\mathrm{O}_{2} \rightarrow \mathrm{CO}_{2}+2 \mathrm{H}_{2} \\
& \mathrm{CH}_{4}+2 \mathrm{O}_{2} \rightarrow \mathrm{CO}_{2}+2 \mathrm{H}_{2} \mathrm{O} .
\end{aligned}
$$

Defined process has one main MER, where the most of the methane is converted to carbon monoxide and hydrogen. Methanation reactor in an ATR process generally 
operates between 850 and $1,000{ }^{\circ} \mathrm{C}$ (Lewis and Miller, 2003; Singh and Malhotra, 2004). This high temperature is because of stated POX, shown in Equation (4), and other possible oxidation reactions. At low temperatures a total oxidation reaction, as shown in Equations (5) and (6), is favourable. However, equilibrium conversions greater than $99 \%$ for reforming reaction, stated in Equation (1), are possible at high temperatures (James, 2001). The reforming reactions are performed at 24.1-27.6 bar pressure range. In some cases, it is possible to use a pre-reforming reactor also to increase the yield and avoid the coke formation in reactors by the use of several catalyst types (James, 2001; Lee et al., 2004). This application brings additional cost and requires different catalysts and design configurations of course. In addition, a Water-Gas Shift (WGS) reaction, Equation (3), takes place in the MER, but the conversion is not so much. The exothermic WGS equilibrium reaction taking place in both reforming and $\mathrm{CO}$ sequestration stages, shift reactors, is as follows:

$$
\mathrm{CO}+\mathrm{H}_{2} \mathrm{O} \leftrightarrow \mathrm{CO}_{2}+\mathrm{H}_{2} .
$$

The shift reaction, as shown in Equation (3), is mostly carried out with one WGS reactor but two shift reactors are favourable in large scale plants. In simulated process, one High Temperature Shift (HTS) and one Low Temperature operating Shift (LTS) equilibrium reactors are used (Ogden, 2001). HTS reactors operates at about $350-475{ }^{\circ} \mathrm{C}$ and the LTS reactors operates at about $200-250^{\circ} \mathrm{C}$ (Lee et al., 2004; Baloğlu and Nasun-Saygil1, 2005). The operating pressure for both units is the same as MER. The CO conversion achieved is generally at about $90-95 \%$ with two shift reactors in series and with the defined operating conditions (Miller and Stöcker, 1989). The reactor operating conditions of the simulated process are shown in Table 3. Both shift reactors are followed by cooler heat exchangers as seen in the Process Flow Diagram (PFD) for the simulation in Figure 1. The operating conditions of the heat exchangers are also given in Table 4 . Moreover, the operating conditions of the other process equipments are given, compressors and expanders in Table 5 and flash and component separator units' in Table 6.

However as stated before, the coke formation is possible in the plant depending upon the operating conditions. The solid carbon or $\mathrm{CO}_{2}$ formation possibilities of all carbon containing streams are stated in Table 7 to emphasise the consistency of the simulated process also.

Table 3 Reactor operating conditions

\begin{tabular}{lccc}
\hline Equipment ID & $R-101$ & $R-102$ & $R-103$ \\
\hline Stream name & & & \\
Pressure (bar) & 25.00 & 25.00 & 25.00 \\
Temperature $\left({ }^{\circ} \mathrm{C}\right)$ & 900.00 & 350.00 & 200.00 \\
Heat duty (MJ hour ${ }^{-1}$ ) & $49,373.31$ & $-6,817.51$ & $-2,283.69$ \\
Phase & vapour & vapour & vapour \\
Heat of reaction $\left(\mathrm{MJ} \mathrm{hour}^{-1}\right)$ & $44,385.56$ & $-7,487.99$ & $-2,283.69$ \\
No. of reactions & 3 & 1 & 1 \\
Calculation mode & $1 *$ & $2 * *$ & $2 * *$ \\
\hline
\end{tabular}

*Equilibrium equations solved by temperature difference and **equilibrium equations solved by equilibrium fraction. 
Figure 1 (a) Process Flow Diagram of Simulated ATR Plant; (b) Carbon dioxide separation sub process; (c) Hydrogen separation sub process

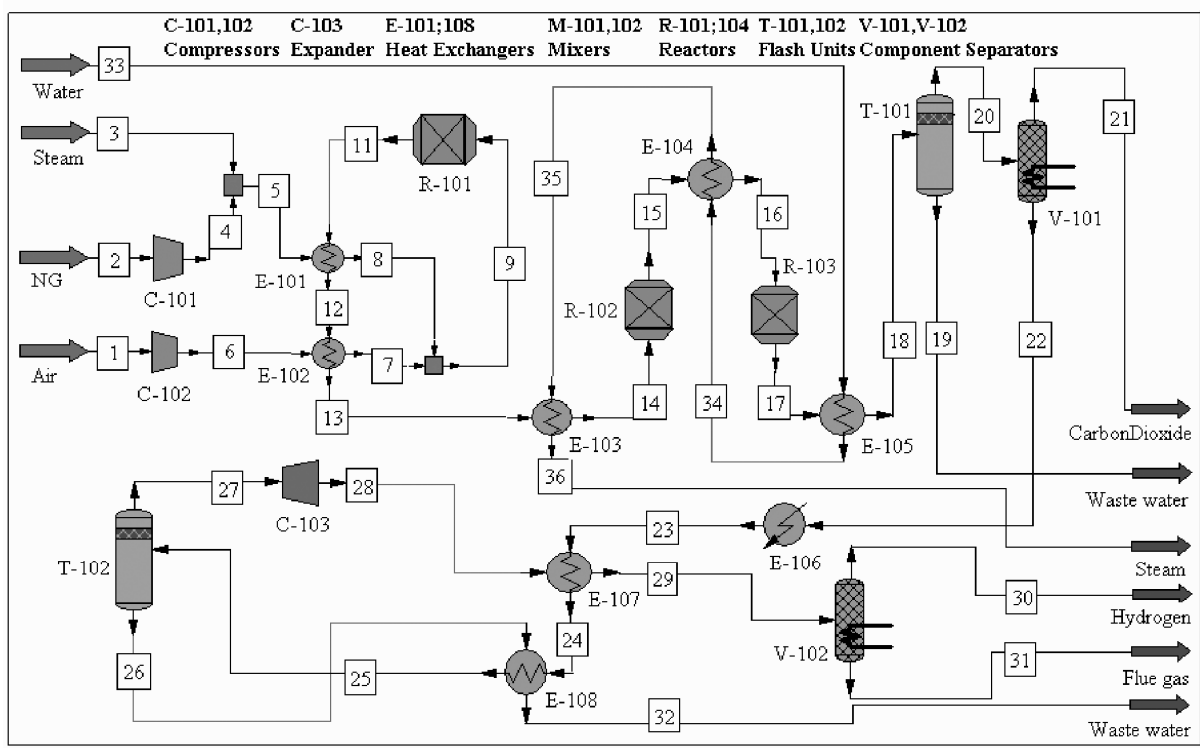

(a)

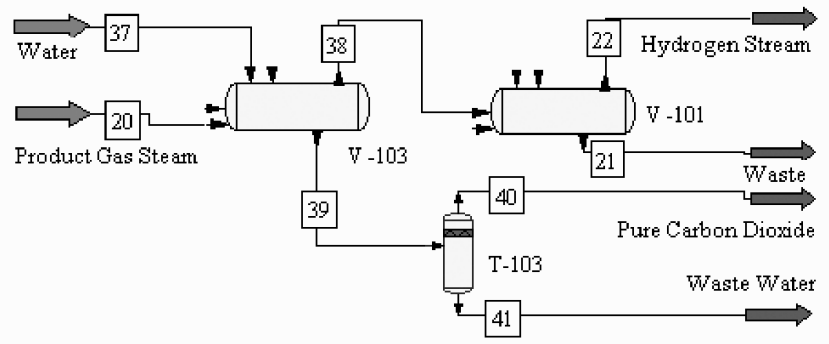

(b)

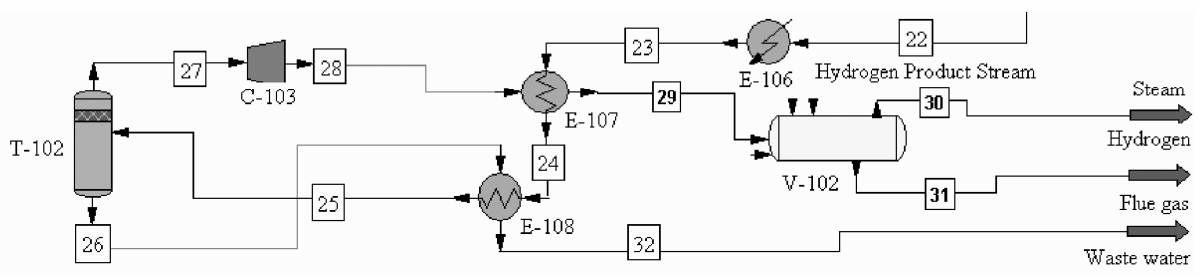

(c) 
Table 4 Heat exchanger operating conditions

\begin{tabular}{|c|c|c|c|c|c|c|c|c|}
\hline Equipment ID & $E-101$ & $E-102$ & $E-103$ & $E-104$ & $E-105$ & $E-106$ & $E-107$ & $E-108$ \\
\hline \multicolumn{9}{|l|}{ Stream name } \\
\hline $\begin{array}{l}\text { Temperature out } \\
\text { (process) }\left({ }^{\circ} \mathrm{C}\right)\end{array}$ & 750.00 & 625.00 & 350.00 & 200.00 & 35.00 & -10.00 & -80.00 & -80.00 \\
\hline $\begin{array}{l}\text { Pressure out } \\
\text { (process) (bar) }\end{array}$ & 25.00 & 25.00 & 25.00 & 25.00 & 25.00 & 35.46 & 1.00 & 95.08 \\
\hline $\begin{array}{l}\text { CHD } \\
\left(\mathrm{MJ} \mathrm{hour}^{-1}\right)\end{array}$ & $22,348.53$ & 74.37 & $8,210.06$ & $8,064.48$ & $12,883.87$ & $-1,745.58$ & $2,883.70$ & 24.97 \\
\hline LMTD $\left({ }^{\circ} \mathrm{C}\right)$ & 211.30 & 127.73 & 187.23 & 65.04 & 14.45 & 34.4 & 62.30 & 27.63 \\
\hline
\end{tabular}

Table 5 Compressor and expander operating conditions

\begin{tabular}{lrrr}
\hline Equipment ID & $C-101$ & \multicolumn{1}{c}{$C-102$} & \multicolumn{1}{c}{-103 } \\
\hline Stream name & & & \\
Pressure out (bar) & 25.00 & 25.00 & 1.00 \\
Theoretical Power $\left(\mathrm{MJ} \mathrm{hour}^{-1}\right)$ & 765.16 & $2,493.35$ & $-5,965.63$ \\
Efficiency & 0.75 & 0.75 & 0.75 \\
Actual Power (MJ hour & -1 & $3,324.46$ & $-4,474.22$ \\
$\mathrm{Cp} / \mathrm{Cv}$ & $1,020.21$ & 1.39 & 1.45 \\
Ideal Cp/Cv & 1.33 & 1.39 & 1.41 \\
\hline
\end{tabular}

Table 6 Flash and component separator operating conditions

\begin{tabular}{|c|c|c|c|c|c|c|}
\hline Equipment ID & $T-101$ & $T-102$ & $T-103$ & $V-101$ & $V-102$ & $V-103$ \\
\hline \multicolumn{7}{|l|}{ Stream name } \\
\hline Temperature $\left({ }^{\circ} \mathrm{C}\right)$ & 30.00 & -25.00 & 30.00 & -110.00 & -83.50 & 5.00 \\
\hline Pressure (bar) & 95.00 & 30.00 & 1.00 & 40.00 & 1.03 & 120 \\
\hline CHD (MJ hour $\left.{ }^{-1}\right)$ & 542.63 & $2,543.21$ & $13,433.20$ & $-4,592.90$ & $-2,330.71$ & $-13,705.18$ \\
\hline
\end{tabular}

Table $7 \quad \mathrm{CO}_{2}$ solid prediction (valid range from -135 to $-57^{\circ} \mathrm{C}$ )

\begin{tabular}{lcccc}
\hline Stream no & Temperature $\left({ }^{\circ} \mathrm{C}\right)$ & Pressure (bar) & Fugacity (bar) & Solid point $\left({ }^{\circ} \mathrm{C}\right)$ \\
\hline 2 & 25.00 & 10.00 & 0.05 & -106.14 \\
4 & 134.51 & 25.00 & 0.12 & -97.87 \\
5 & 215.08 & 25.00 & 0.04 & -107.43 \\
8 & 750.00 & 25.00 & 0.04 & -107.29 \\
9 & 735.36 & 25.00 & 0.04 & -108.98 \\
11 & 900.00 & 25.00 & 0.64 & -81.61 \\
12 & 502.45 & 25.00 & 0.64 & -81.62 \\
13 & 503.83 & 25.00 & 0.64 & -81.62 \\
14 & 350.00 & 25.00 & 0.64 & -81.67 \\
15 & 350.00 & 25.00 & 3.39 & -60.49 \\
16 & 200.00 & 25.00 & 3.35 & -60.68 \\
17 & 200.00 & 25.00 & 4.23 & -57.03 \\
\hline
\end{tabular}


Table $7 \quad \mathrm{CO}_{2}$ solid prediction (valid range from -135 to $-57^{\circ} \mathrm{C}$ ) (Continued)

\begin{tabular}{lcccc}
\hline Stream no & Temperature $\left({ }^{\circ} \mathrm{C}\right)$ & Pressure (bar) & Fugacity (bar) & Solid point $\left({ }^{\circ} \mathrm{C}\right)$ \\
\hline 18 & 35.00 & 25.00 & 4.31 & -56.73 \\
19 & 47.07 & 30.00 & 22.21 & -23.73 \\
20 & 47.07 & 30.00 & 5.15 & -53.77 \\
21 & 35.00 & 35.46 & 30.05 & -15.91 \\
\hline
\end{tabular}

\subsection{Cryogenic subprocess}

Before the hydrogen separation unit the residue water from the reforming reactor is eliminated mostly by the flash unit, T-101, as shown on PFD, Figure 1. Following the carbon dioxide sequestration, hydrogen separation is performed. After cooling the product stream with two serial heat exchangers another flash unit is used to get rid of the rest of residue water from reforming. Upper product stream, seen in Figure 1 as stream number 27, of the flash unit is then passed from an expander to utilise the hydrogen product stream as a coolant in heat exchanger, E-107. Generally, last units are component separators in cryogenic separation systems as in the simulated process. Both flash units defined in the process are operating isentropically. Operating conditions and the properties of the flash units are given in detail in Table 6.

\subsubsection{Cryogenic separation processes}

In cryogenic separation processes the boiling points of the components are utilised (Miller and Stöcker, 1989). The product streams cooled to certain temperature values to condense the components with appropriate pressure maintenance. The cooling is performed by several heat exchangers and the coolant streams for the heat exchangers are generated by expanders (Whysall and Picioccio, 1999). The product streams consist of hydrogen are passed through the expanders and used as a coolant generally, but if the amount is not enough the required refrigerant is supplied from outside of the plant. After maintaining the required temperature and pressure conditions to condense the unwanted components, the product stream is divided into two phases and sent to a component separator (Whysall and Picioccio, 1999). Component separator separates the product that has the relatively high volatility. Here, hydrogen has the higher volatility in the product stream. The cryogenic separation processes are generally used in hydrocarbon separation processes (Miller and Stöcker, 1989). Hydrogen purities up to 97\%, hydrogen recovery up to $98 \%$ is possible with cryogenic processes. Cryogenic separation processes are thermodynamically more efficient than the other separation techniques for hydrogen and hydrogen is recovered easily but not at high percents as from membrane or Pressure Swing Adsorption (PSA) separations (Miller and Stöcker, 1989).

\subsubsection{Component separators used for cryogenic separations}

Component separator module defined in the simulation programme is imaginary equipment. This module is defined as a black-box separator which splits an input stream into two output streams of different compositions and thermal conditions. This means that almost any kind of separation is possible with this equipment. So, the designer should decide which equipment is to be used for the performed separation. 
Sensitivity analysis in a simulated auto thermal $N G$ reforming process

Table $8 \quad \mathrm{CO}_{2}$ separator inlet and outlet stream compositions and properties

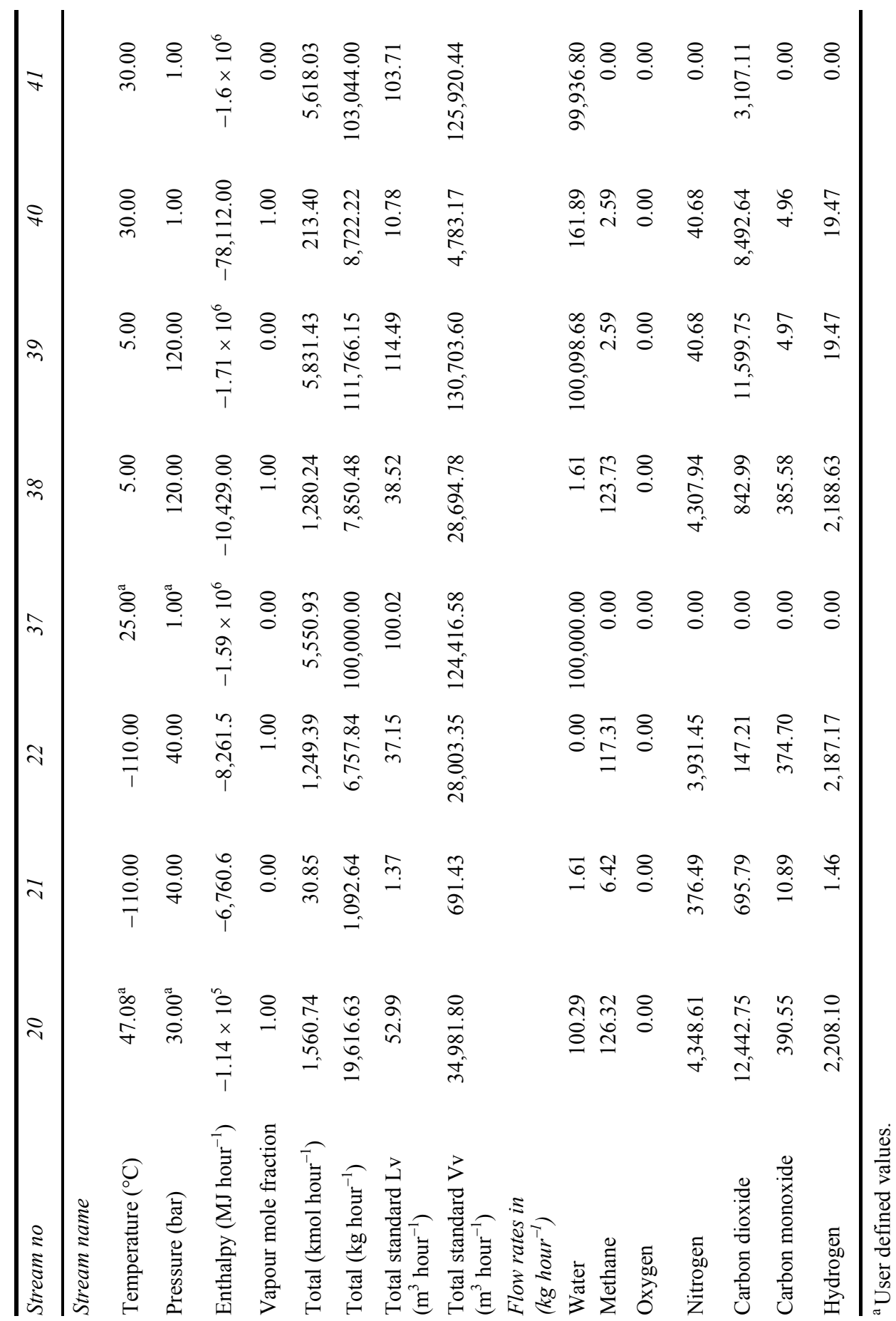


In the simulated process for $\mathrm{H}_{2}$ and $\mathrm{CO}_{2}$ separation one component separator were used for each. Instead of component separators in simulation the dynamic vessel modules that operate same as flash units are used for the actual separation. Here in this article, dynamic vessel modules will be also called as component separators. The operating conditions, the detailed inlet and outlet stream properties for component separators considering the base case are given in Tables 6 and 8 .

In sensitivity studies both $\mathrm{H}_{2}$ and $\mathrm{CO}_{2}$ separators operating conditions are examined. The component separators are simulated for certain temperature and pressure ranges to determine the effects on the separation. The actual stream compositions of the base case used for the sensitivity studies are given on Table 8 and Table 9 with appropriate stream numbers shown on Figure 1(b) and (c).

Table $9 \mathrm{H}_{2}$ separator stream compositions and properties

\begin{tabular}{lrrr}
\hline Stream no & \multicolumn{1}{c}{39} & \multicolumn{1}{c}{31} \\
\hline Stream name & & & \\
Temperature $\left({ }^{\circ} \mathrm{C}\right)$ & $-80.00^{\mathrm{a}}$ & -135.00 & -135.00 \\
Pressure (bar) & $1.00^{\mathrm{a}}$ & 55.00 & 55.00 \\
Enthalpy (MJ hour $\left.{ }^{-1}\right)$ & $-5,946.10$ & $-5,051.60$ & $-3,224.90$ \\
Vapour mole fraction & 1.00 & 1.00 & 0.00 \\
Total $\left(\mathrm{kmol} \mathrm{hour}^{-1}\right)$ & $1,272.46$ & $1,038.42$ & 234.04 \\
Total $\left(\mathrm{kg} \mathrm{hour}^{-1}\right)$ & $7,074.29$ & $2,177.71$ & $4,896.58$ \\
Total standard $\mathrm{Lv}\left(\mathrm{m}^{3}\right.$ hour $\left.^{-1}\right)$ & 37.84 & 29.98 & 7.86 \\
Total standard Vv $\left(\mathrm{m}^{3}\right.$ hour $\left.^{-1}\right)$ & $28,520.52$ & $23,274.76$ & $5,245.77$ \\
Flowrates in $\left(\mathrm{kg} \mathrm{hour}^{-1}\right)$ & & & 0.19 \\
Water & 0.19 & 0.00 & 85.93 \\
Methane & 126.33 & 40.41 & 0.00 \\
Oxygen & 0.00 & 0.00 & $4,317.88$ \\
Nitrogen & $4,349.11$ & 31.23 & 0.00 \\
Carbon dioxide & 0.00 & 0.00 & 368.86 \\
Carbon monoxide & 390.57 & 21.72 & 123.72 \\
Hydrogen & $2,208.08$ & $2,084.36$ & \\
\hline
\end{tabular}

${ }^{\text {a }}$ User defined values.

\section{Results and discussion}

\subsection{Effects of feed stream $\mathrm{O}_{2} / \mathrm{C}$ or air/C ratios on the process}

The base case for sensitivity analysis is $5,000 \mathrm{~kg} \mathrm{~h}^{-1} \mathrm{NG}$ feed. The appropriate air and steam feed for this capacity is, respectively, 5,481 and 10,943 $\mathrm{kg} \mathrm{h}^{-1}$. Feed assumptions and detailed stream properties for the base case are given in Tables 1 and 2. The $\mathrm{H}_{2} \mathrm{O} / \mathrm{C}$ mass ratio, considering these feed amounts, is 3.0 and $\mathrm{O}_{2} / \mathrm{C}$ mass ratio is 0.35 for the base case. The overall process is examined with different air feed amounts, from $3,132 \mathrm{~kg} \mathrm{~h}^{-1}$ or $110 \mathrm{kmol} \mathrm{h}^{-1}$ to $13,312 \mathrm{~kg} \mathrm{~h}^{-1}$ or $465 \mathrm{kmol} \mathrm{h}^{-1}$. This range is given in $\mathrm{O}_{2} / \mathrm{C}$ mass ratio as from 0.2 to 0.85 . While changing the air feed amount the $\mathrm{H}_{2} \mathrm{O} / \mathrm{C}$ mass ratio (3.0) and the other parameters are stayed constant. The stream compositions monitored by the stated air feed amount range is as seen in Figure 2 in terms of air feed amounts. It is clear that increasing the air feed increases the hydrogen and carbon dioxide formation and after 
a certain amount the residue water from reforming increase. However, the residue methane and carbon monoxide decreases with increasing air feed amount.

Figure 2 Component flow rates for different air feed amounts (for constant $\mathrm{H}_{2} \mathrm{O} / \mathrm{C}: 3$ (w/w) ratio)

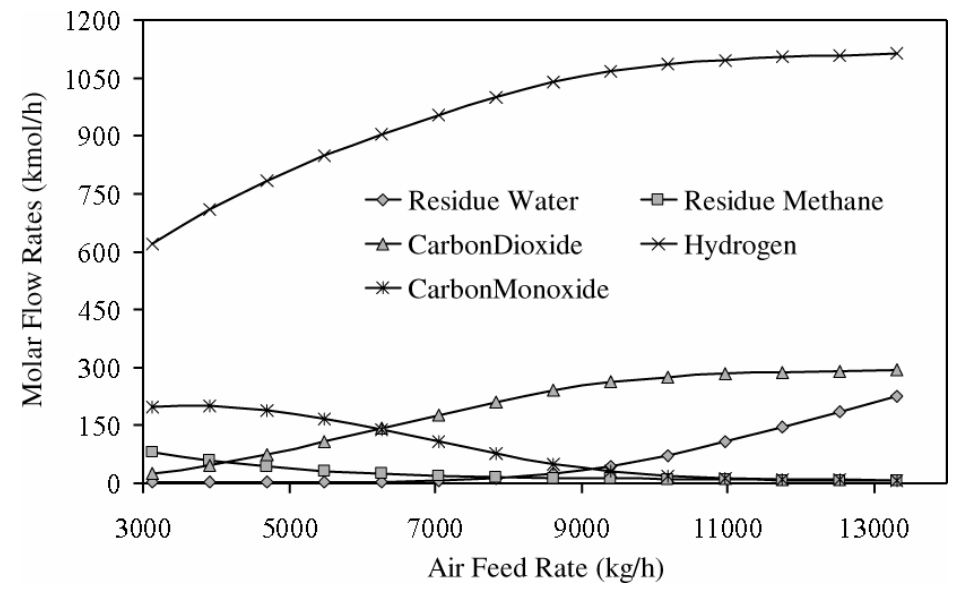

Figure 3 Component flow rates for different $\mathrm{O}_{2} / \mathrm{C}$ ratios (for constant $\mathrm{H}_{2} \mathrm{O} / \mathrm{C}: 3$ (w/w) ratio)

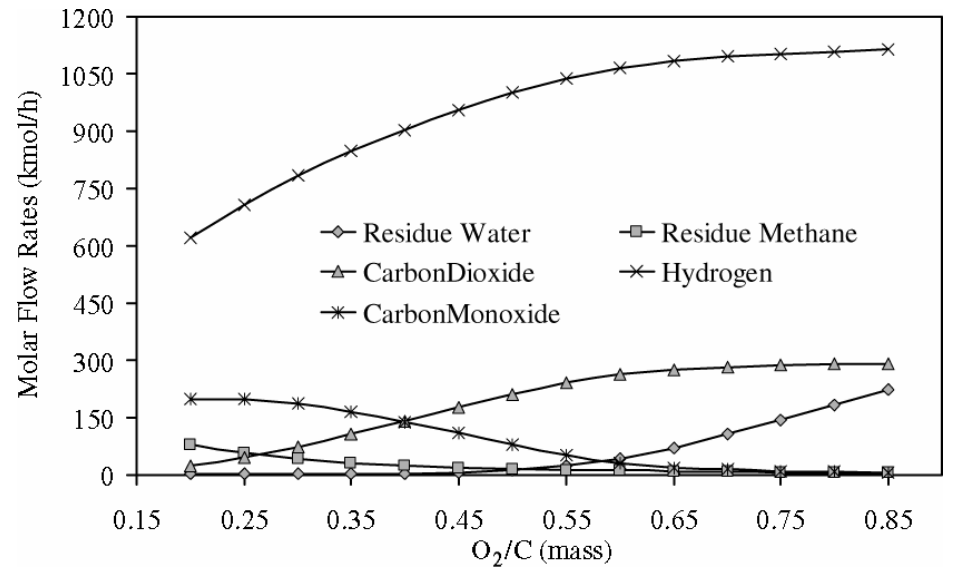

Figure 2 is shown in Figure 3 in terms of $\mathrm{O}_{2} / \mathrm{C}$ ratios. The hydrogen generation does not change so much at higher values of $\mathrm{O}_{2} / \mathrm{C}$ ratio after 0.75 . Residue water increases after the ratio of 0.55 and the hydrogen formation begins to drop below the $\mathrm{O}_{2} / \mathrm{C}$ ratio of 0.3 as seen in Figure 3.

\subsection{Effects of $\mathrm{H}_{2} \mathrm{O} / \mathrm{C}$ ratio or steam feed amount on the process}

The water steam amount is varied between $12,767 \mathrm{~kg} \mathrm{~h}^{-1}$ (or $709 \mathrm{kmol} \mathrm{h}^{-1}$ ) and $8,389 \mathrm{~kg} \mathrm{~h}^{-1}$ (or $466 \mathrm{kmol} \mathrm{h}^{-1}$ ) and the changes resulted among the varied steam feed rates are given in Figure 4. Figure 4 reveals that excess steam after certain feed amounts, does not have any apparent affect on reforming. The waste water amount left from reforming and $\mathrm{CO}$ sequestration percent is increasing with increasing steam feed. Figure 4 is shown in Figure 5 in terms of $\mathrm{H}_{2} \mathrm{O} / \mathrm{C}(\mathrm{w} / \mathrm{w})$ ratios. It can be resulted from this 
figure that at greater values of $\mathrm{H}_{2} \mathrm{O} / \mathrm{C}$ ratios, above 3.0-3.2, the hydrogen generation is not desirable. $\mathrm{CO}$ sequestration will be easy and duty of the flash units for waste water removal will increase apparently at higher ratios.

Figure 4 Component flow rates for different steam feed amounts (constant $\mathrm{O}_{2} / \mathrm{C}: 0.35$ ratio)

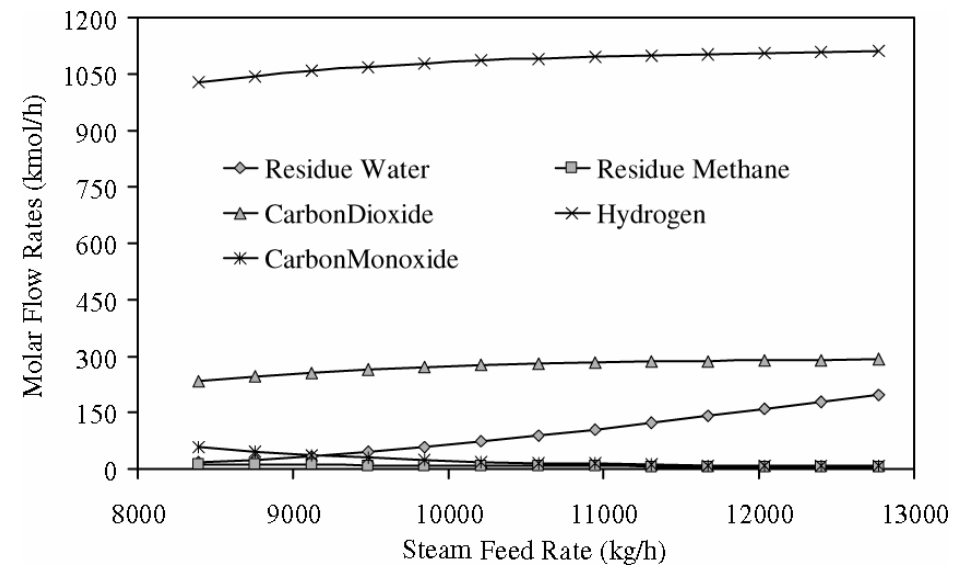

Figure 5 Component flow rates for different $\mathrm{H}_{2} \mathrm{O} / \mathrm{C}$ ratios (constant $\mathrm{O}_{2} / \mathrm{C}: 0.35$ ratio)

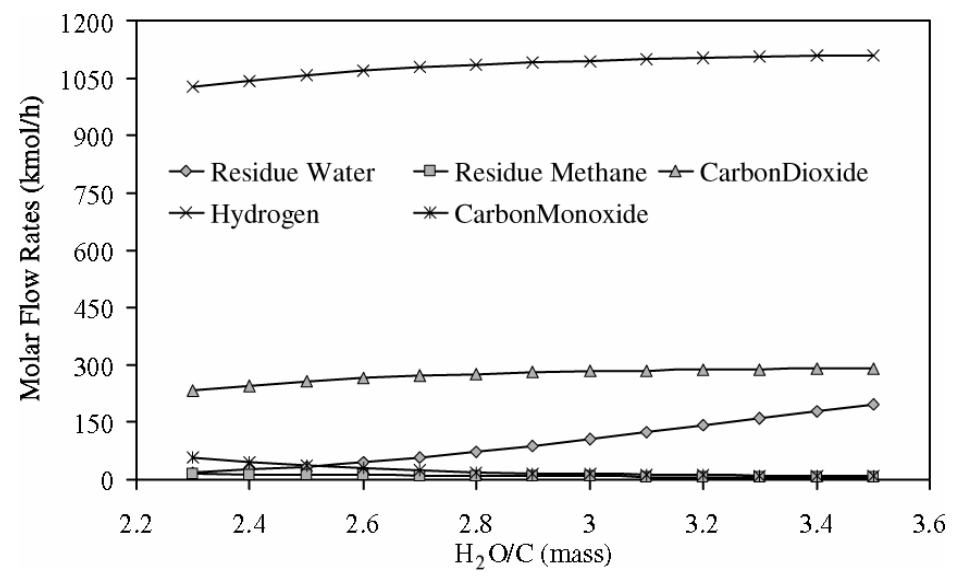

\subsection{Effects of capacity increments in the simulated Auto Thermal Natural Gas Reforming process}

In ATR plant for hydrogen generation increasing the capacity results in enormous increase in $\mathrm{CO}_{2}$ production. The capacity of the simulated process is increased from 3,500 $\left(\mathrm{kg} \mathrm{h}^{-1}\right)$ to $8,000\left(\mathrm{~kg} \mathrm{~h}^{-1}\right)$ with constant operating conditions and parameters, like $\mathrm{H}_{2} \mathrm{O} / \mathrm{C}$ ratio of 3 and $\mathrm{O}_{2} / \mathrm{C}$ ratio of 0.35 . The results are shown and this fact is proved by Figure 6. From Figure 6, it can be seen that the greater the capacity the greater the $\mathrm{CO}_{2}$ release is. The importance of $\mathrm{CO}_{2}$ handling in $\mathrm{NG}$ reforming plants is once again shown 
by this graph. The other component mass flow rate increments are not as effective as $\mathrm{CO}_{2}$ as seen in Figure 6.

Figure 6 Component flow rates for different plant capacity $\left(\mathrm{H}_{2} \mathrm{O} / \mathrm{C}: 3\right.$ and $\left.\mathrm{O}_{2} / \mathrm{C}: 0.35\right)$

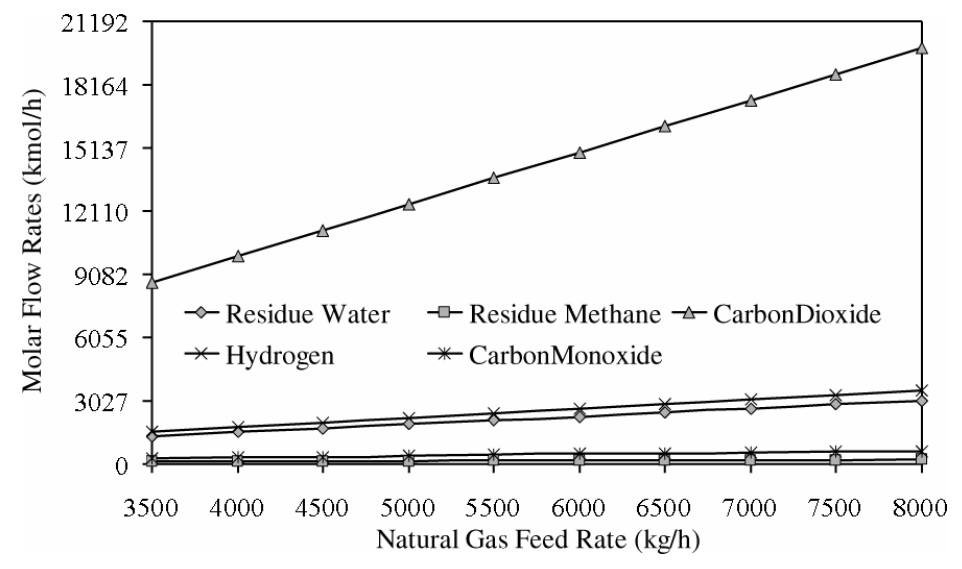

Figure 7 Effect of main reformer temperature on reforming

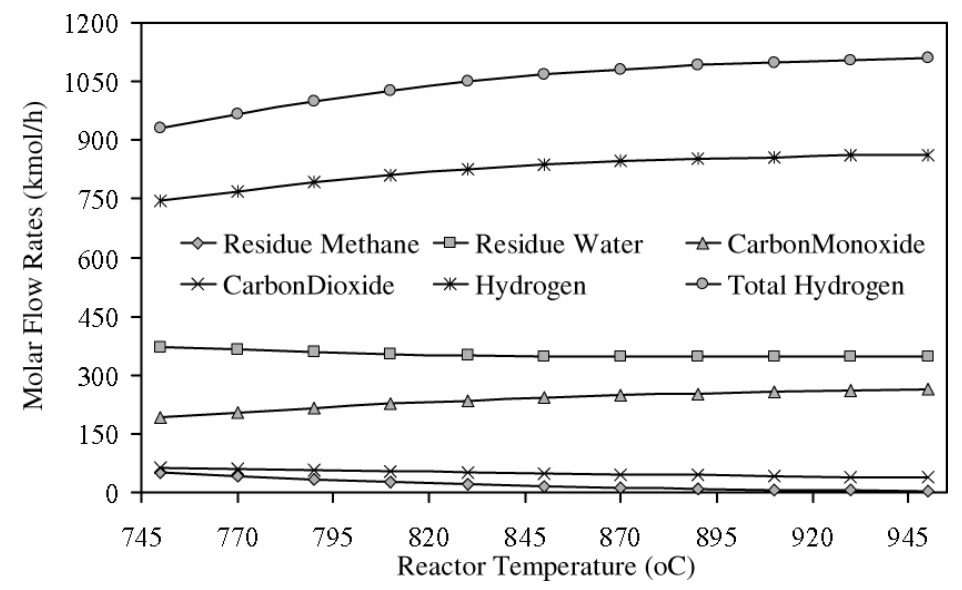

\subsection{Effects of methanation and shift equilibrium reactor operating temperatures}

Reforming temperature enhancement is very important in reforming processes because of the high cost of construction materials and the catalyst activity in reactors. The higher the operating temperature of the reformer the higher the cost is. Thus, the temperature effect of the reforming reactors on the general process was investigated. The main reformer always operates at higher temperatures than the shift reactors. First, the process was simulated several times for the main reformer temperatures between 750 and $950{ }^{\circ} \mathrm{C}$ and the resulting component molar flow rates are released in Figure 7. High temperature on main reformer, apparently as seen in Figure 7, increases the hydrogen generation. On the 
other hand, increasing reforming temperature of the main reformer increases the $\mathrm{CO}$ and $\mathrm{CO}_{2}$ formation decreases the residue methane and steam from reforming.

However, same considerations in main reforming reactor do not apply to the shift reactors. Considering the literature values given for shift reactors (Lee et al., 2004; Baloğlu and Nasun-Saygil1, 2005), HTS reactor operating temperature is varied from 300 to $500{ }^{\circ} \mathrm{C}$ to examine the results on the process outlet streams. Figure 8 clearly summarises results. Also, the LTS reactor operating temperature is varied from 150 to $350{ }^{\circ} \mathrm{C}$ and results are given in Figure 9. From both Figures 8 and 9, it can be revealed that $\mathrm{CO}$ sequestration is not favourable at extremely high temperatures. It is resulted from Figure 8 that also with increasing shift reactor temperature decreases $\mathrm{CO}, \mathrm{H}_{2} \mathrm{O}$ conversion to $\mathrm{CO}_{2}$ and hydrogen. Equilibrium conversions for shift reaction, stated in Equation (6), are favourable at lower temperatures considering the high reforming temperature examined before. This is mostly because of the exothermic shift equilibrium reaction, high operating pressures and inert components in the reactor like $\mathrm{N}_{2}$.

Figure 8 Effect of High Temperature Shift reactor temperature on reforming

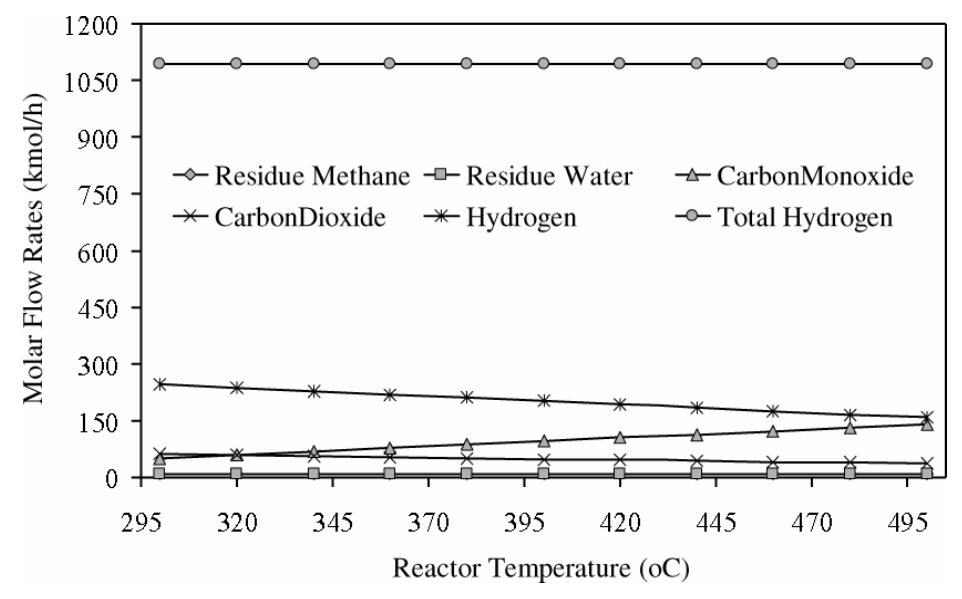

Figure 9 Effect of Low Temperature Shift reactor temperature on reforming

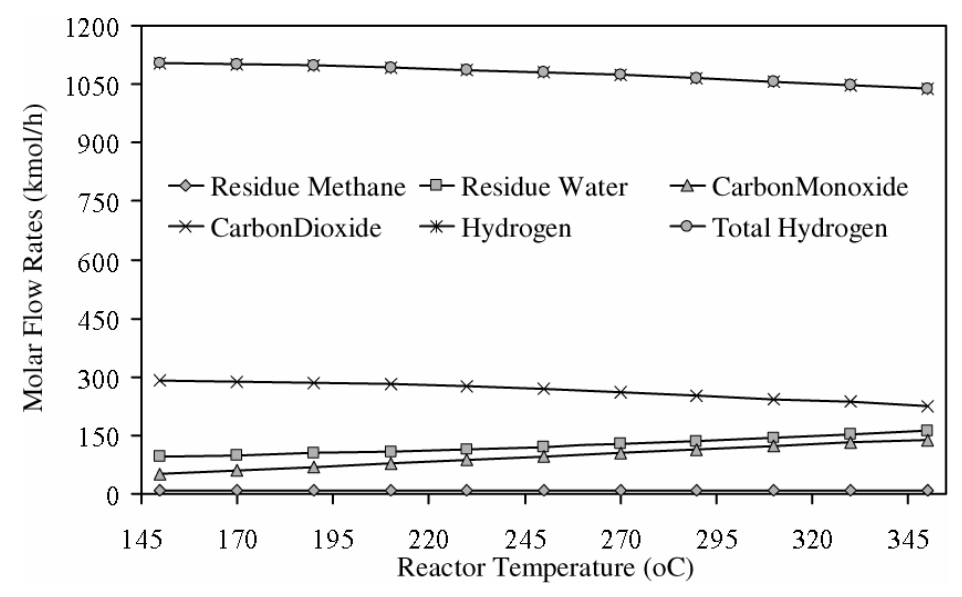


Figure 10 Steam capacity and relating possible steam temperatures

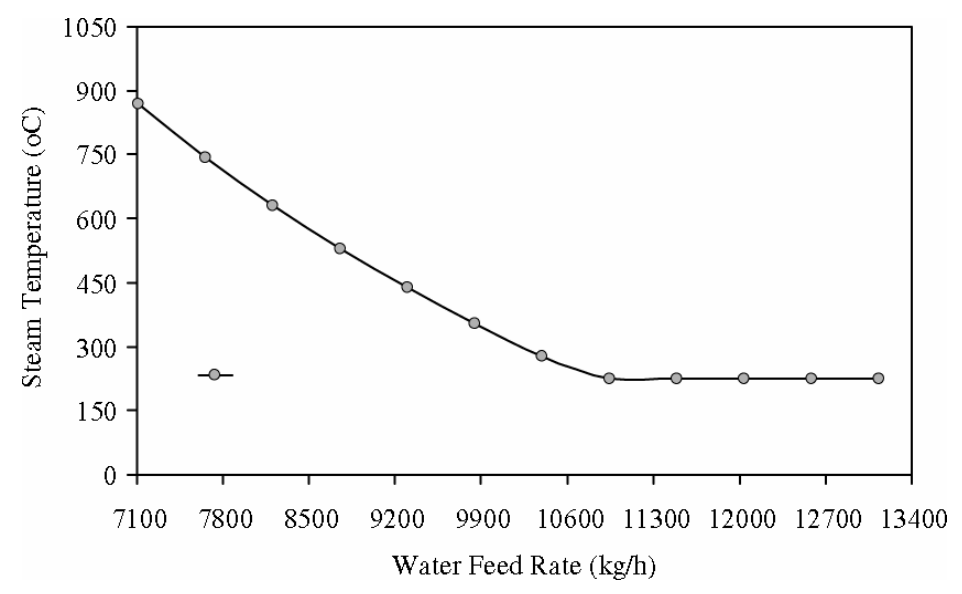

\subsection{Steam generation capacity}

By the equipment sizing studies done for the base case, approximately $234 \mathrm{~m}^{2}$ heat transfer area is determined for one sided heat exchangers. Sixty-five square metre of the heat transfer area is used by self operating heat exchangers to heat or cool the product streams (Baloğlu and Nasun-Saygıll, 2005). The rest of the heat transfer area is used to generate high amounts of superheated steam at high pressures, mostly possible to be used in the facility cycles. The possible steam amounts and the temperatures that can be generated from the simulated process are shown in Figure 10. It is concluded for the base case, e.g. that approximately $95 \%$ of the steam required for the reforming is possible to maintain from the defined process.

\section{6 $\mathrm{CO}_{2}$ sequestration operation conditions}

\subsubsection{Separation by water feed}

The $\mathrm{CO}_{2}$ sequestration for the base case is performed at about 40 bar pressure and $-50{ }^{\circ} \mathrm{C}$ of temperature by the equipment defined as V-101 seen on PFD, Figure 1. The operating conditions and the stream compositions for the base case used are given in Tables 6 and 8 . For the base case, without water feed to the component separator, at about $19 \%$ of the $\mathrm{CO}_{2}$ in hydrogen stream is removed for the same operating conditions. The $\mathrm{CO}_{2}$ amounts left in the hydrogen stream after several water feed rates to the component separator are shown in Figure 11. To distinguish the pressure effect in addition to the water feed the operating pressure is doubled and the results are shown in Figure 12. Again from both graphs it can be seen that increasing both the pressure and water feed increases the $\mathrm{CO}_{2}$ removal.

Nevertheless, for the base case the $\mathrm{CO}_{2}$ separator is simulated several times within a certain operating pressure range at $-55^{\circ} \mathrm{C}$ temperature. The product hydrogen stream composition change is given in Figure 13. Also, the operating temperature effect on the $\mathrm{CO}_{2}$ separation at a pressure of $40 \mathrm{bar}$ is shown in Figure 14. Figure 13 describes the pressure values about $25-75$ bar is favourable for $\mathrm{CO}_{2}$ separation with appropriate water feed at a temperature of $-55{ }^{\circ} \mathrm{C}$ and the optimum temperature range for $\mathrm{CO}_{2}$ separation is about -110 and $-130{ }^{\circ} \mathrm{C}$ at a pressure of 40 bar resulted from Figure 14 . 
Figure 11 Effect of water feed rate to the $\mathrm{CO}_{2}$ separator (for the base case (40 bars and $-50{ }^{\circ} \mathrm{C}$ )) (see online version for colours)

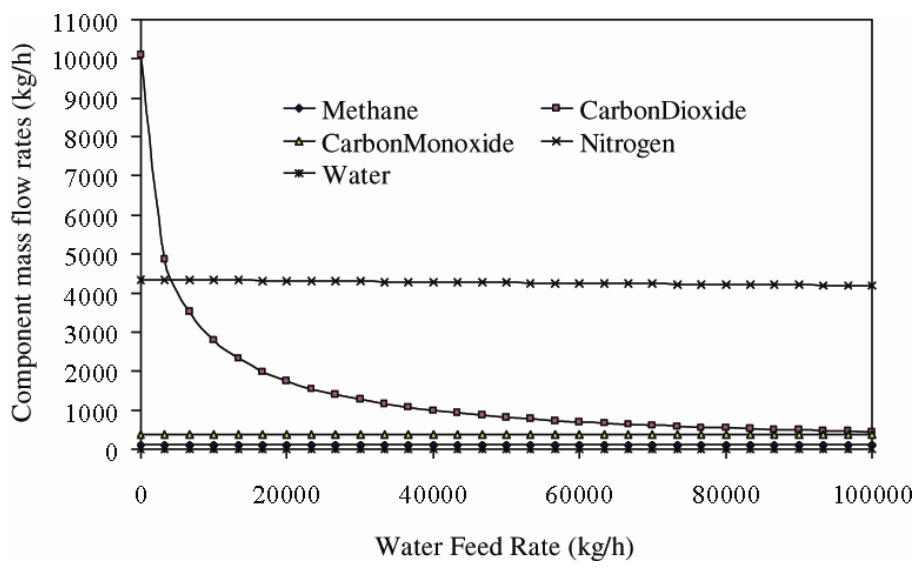

Figure 12 Effect of water feed rate to the $\mathrm{CO}_{2}$ separator for high pressure ( $80 \mathrm{bar}$ and $-50{ }^{\circ} \mathrm{C}$ ) (see online version for colours)

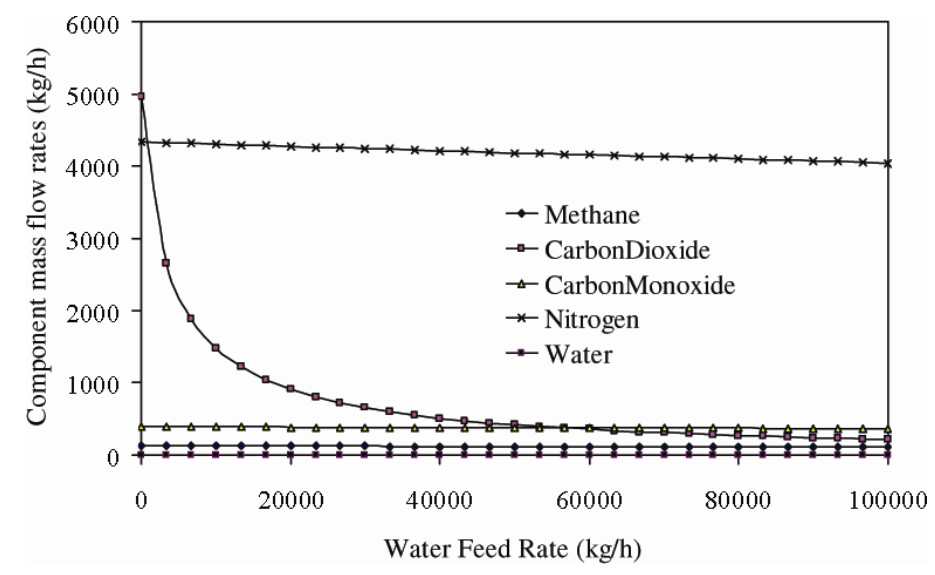

Figure 13 Effect of operating pressure on $\mathrm{CO}_{2}$ separation (with water feed) (see online version for colours)

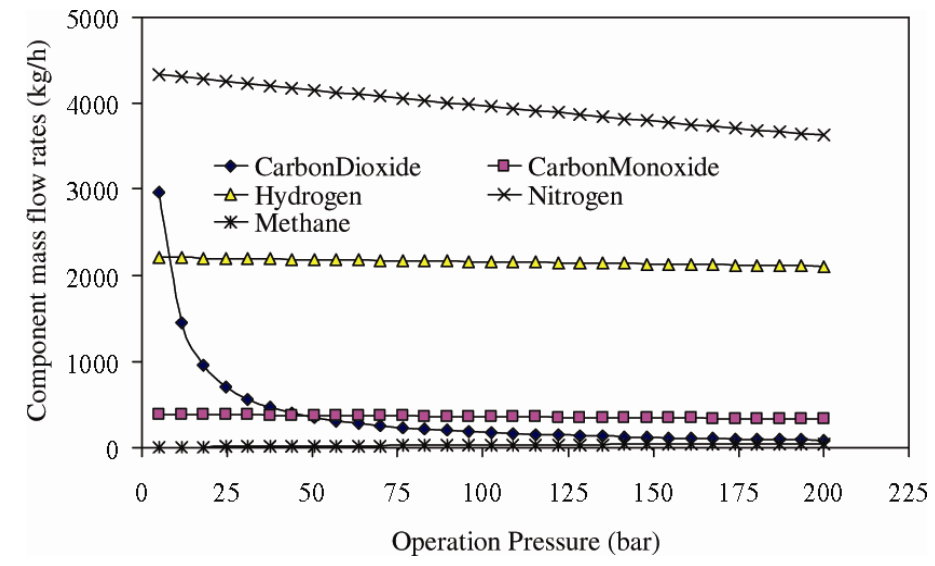


Figure 14 Effect of operating temperature on $\mathrm{CO}_{2}$ separation (with water feed) (see online version for colours)

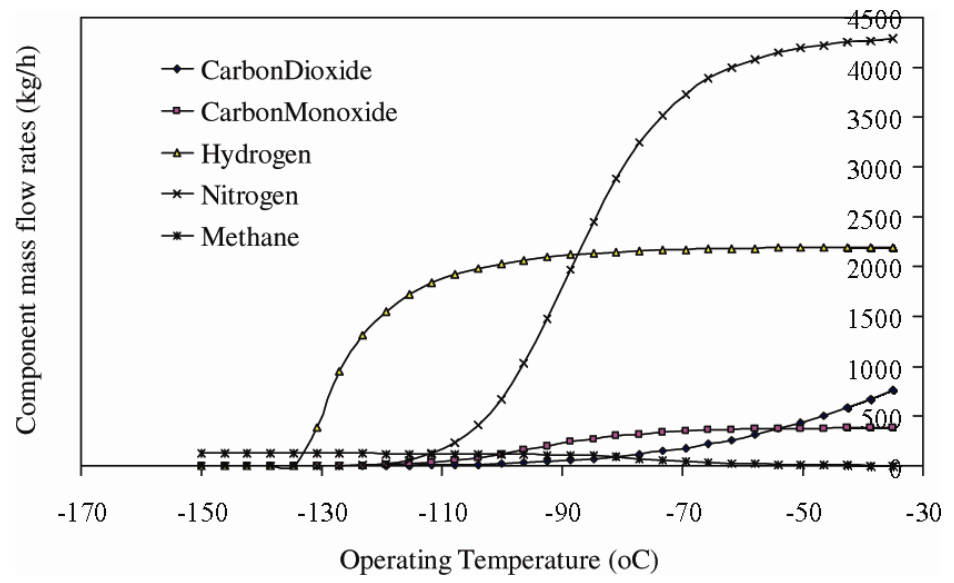

Figure 15 Effect of operating pressure on $\mathrm{CO}_{2}$ separation (for the base case $-50{ }^{\circ} \mathrm{C}$ ) (see online version for colours)

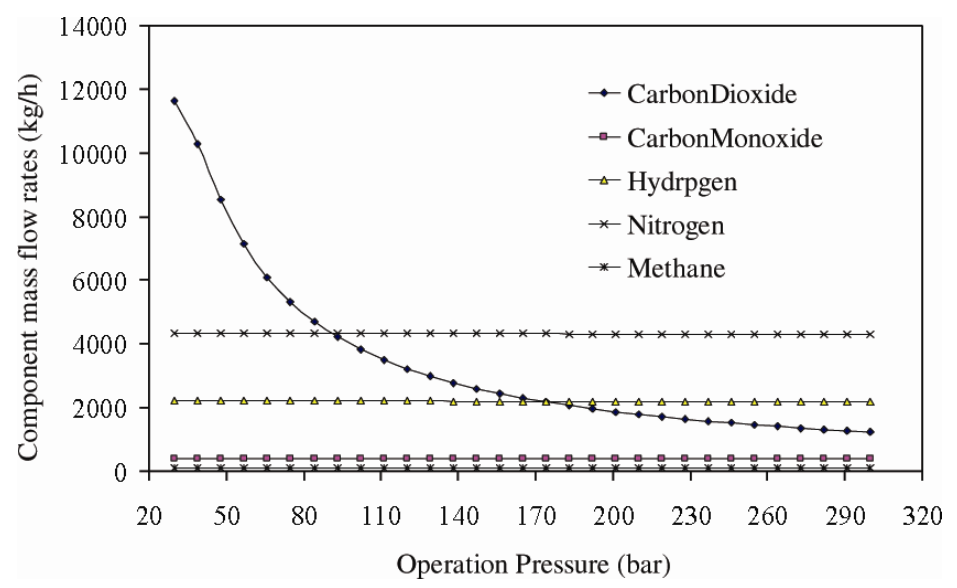

\subsubsection{Separation without water feed}

\subsubsection{Separation pressure}

Without water feed same $\mathrm{CO}_{2}$ removal is approved at high pressures for the constant base case temperature as seen in Figures 15 and 16. Figures 15 and 16 show that the hydrogen stream component mass flow rates of $\mathrm{CO}_{2}$ separator for different pressure values at a temperature of $-50{ }^{\circ} \mathrm{C}$ and $-80{ }^{\circ} \mathrm{C}$, respectively. From Figures 15 and 16 , it can be concluded that decreasing the separation temperature results in decreasing the operating pressure for the same $\mathrm{CO}_{2}$ removal amount at high values. On the other hand, the nitrogen content of the removed $\mathrm{CO}_{2}$ increases with decreasing temperature as seen in Figure $15 . \mathrm{CO}_{2}$ removal at $-50{ }^{\circ} \mathrm{C}$ and about $260-290$ bar is maintained at $-80{ }^{\circ} \mathrm{C}$ at about 80 bars. The other component amounts stay same for both operating conditions as seen on stated figures. 
Figure 16 Effect of operating pressure on $\mathrm{CO}_{2}$ separation (at $-80{ }^{\circ} \mathrm{C}$ ) (see online version for colours)

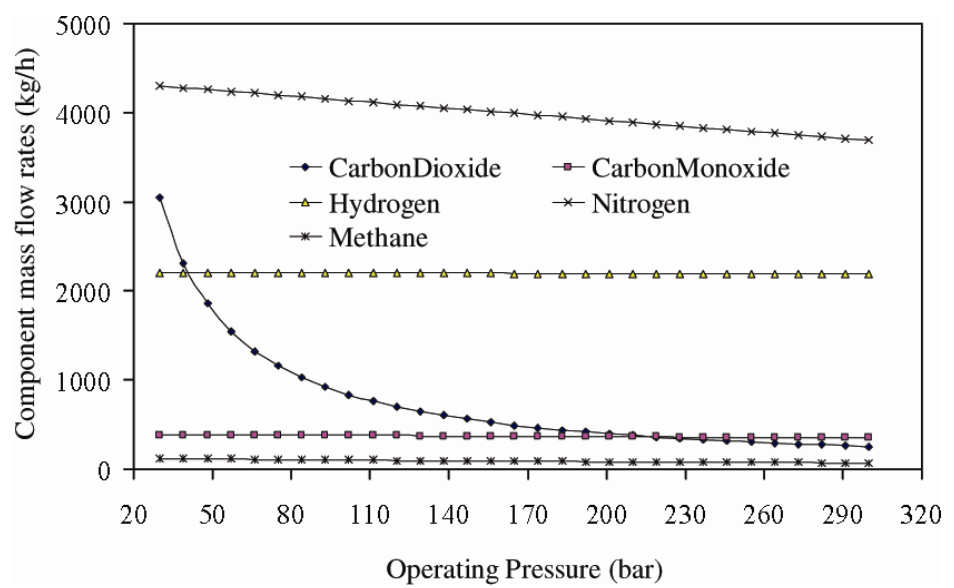

\subsubsection{Separation temperature}

The separation temperature effect is determined within -30 and $-160{ }^{\circ} \mathrm{C}$ temperature range. For this temperature range, the $\mathrm{CO}_{2}$ separator is simulated for two different pressure values. Figures 17 and 18 show that the hydrogen stream component mass flow rates along with the stated temperature range for, respectively, 40 and 80 bar operating pressures of hydrogen component separator. It is resulted from the figures that separation temperature is favourable between -120 and $-140{ }^{\circ} \mathrm{C}$ regardless of pressure. However, the hydrogen product stream is richer in hydrogen at 80 bar operating pressure than at 40 bars although the total hydrogen gain is less. For instance at $-130{ }^{\circ} \mathrm{C}$ for 40 bar operating pressure $94 \%$ (mass) hydrogen purity and total $2,194 \mathrm{~kg} \mathrm{~h}^{-1}$ product stream, for 80 bar $97 \%$ (mass) hydrogen purity and total $1,929 \mathrm{~kg} \mathrm{~h}^{-1}$ product stream is maintained. Considering these facts for the process and required hydrogen purity, the operating conditions for the equipments should be decided.

Figure 17 Effect of operating pressure on $\mathrm{CO}_{2}$ separation (for the base case 40 bar) (see online version for colours)

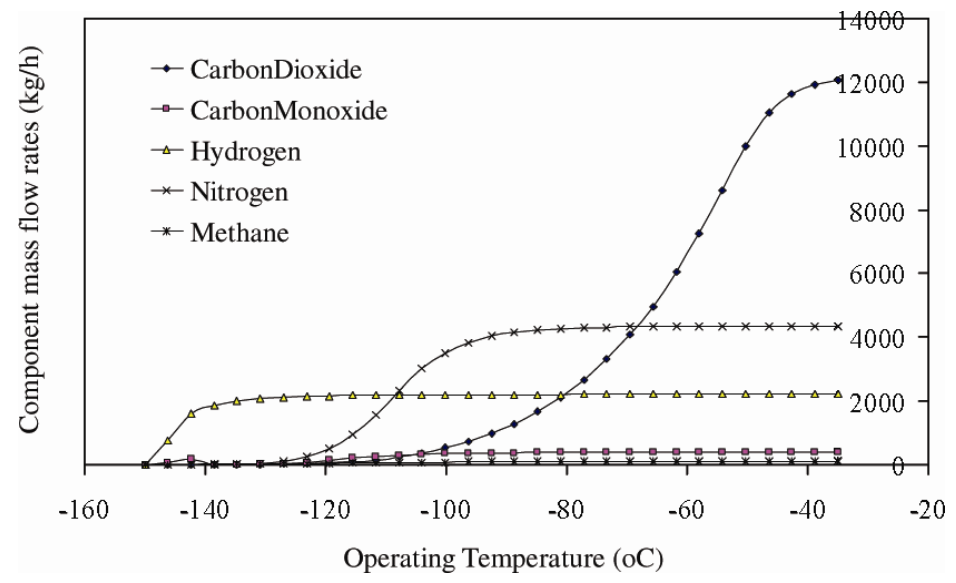


Figure 18 Effect of operating temperature on $\mathrm{CO}_{2}$ separation (at 80 bar) (see online version for colours)

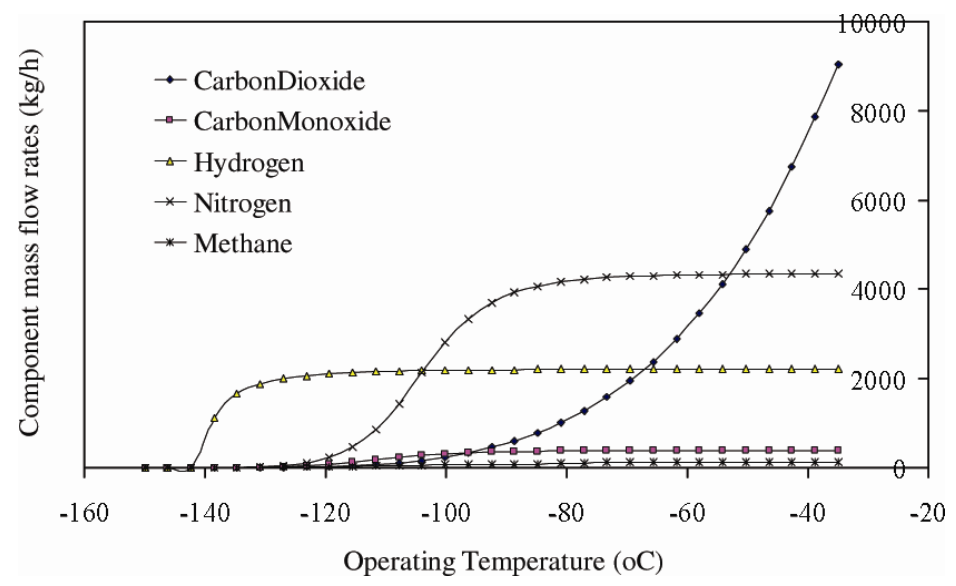

Consequently from Figures 11 through 18 possibility of gaining pure hydrogen without $\mathrm{CO}_{2}$ or $\mathrm{N}_{2}$ sequestration by one separation stage is concluded. In addition, it is resulted from these figures that retrieving the other product stream components by using several component separators operating at appropriate conditions and recycling to the process is also possible.

\section{$3.7 \quad \mathrm{H}_{2}$ separation conditions}

Considering the cryogenic subprocess defined for hydrogen purification, for the sensitivity analysis, as in the $\mathrm{CO}_{2}$ sequestration stage, only the component separator operating conditions are studied. The operating conditions of $\mathrm{H}_{2}$ component separator and stream compositions of this equipment are given in Tables 6 and 9, respectively, for the base case conditions.

\subsubsection{Separation temperature and pressure}

For hydrogen purification, base case operating temperature $-135^{\circ} \mathrm{C}$ and a pressure range of 35-200 bars is studied. The temperature value considered offers a low separation pressure for hydrogen. As seen in Figures 19 and 20 increasing the pressure results in decrease in hydrogen amount in the product stream. Although the hydrogen amount decreases by increasing pressure, the purity of the hydrogen product stream increases. Operating temperature also has a positive effect on this fact as seen in Figure 21. For the base case ( 55 bars), the optimum separation temperature is as seen between 120 and $-150{ }^{\circ} \mathrm{C}$, the base case operating temperature is also between these values. 
Figure 19 Effect of operating pressure on $\mathrm{H}_{2}$ separation (for the base case $-135^{\circ} \mathrm{C}$ ) (see online version for colours)

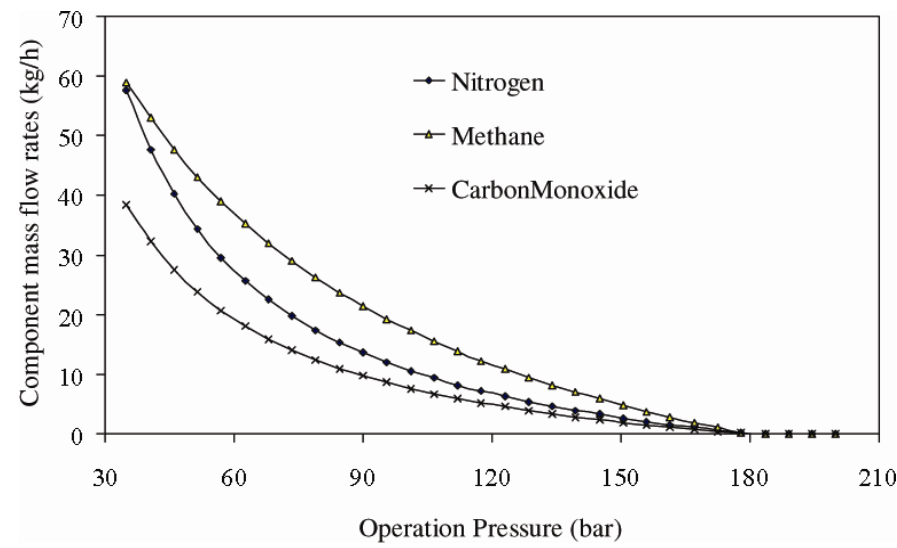

Figure 20 Effect of operating pressure on $\mathrm{H}_{2}$ separation (for the base case $-135{ }^{\circ} \mathrm{C}$ ) (see online version for colours)

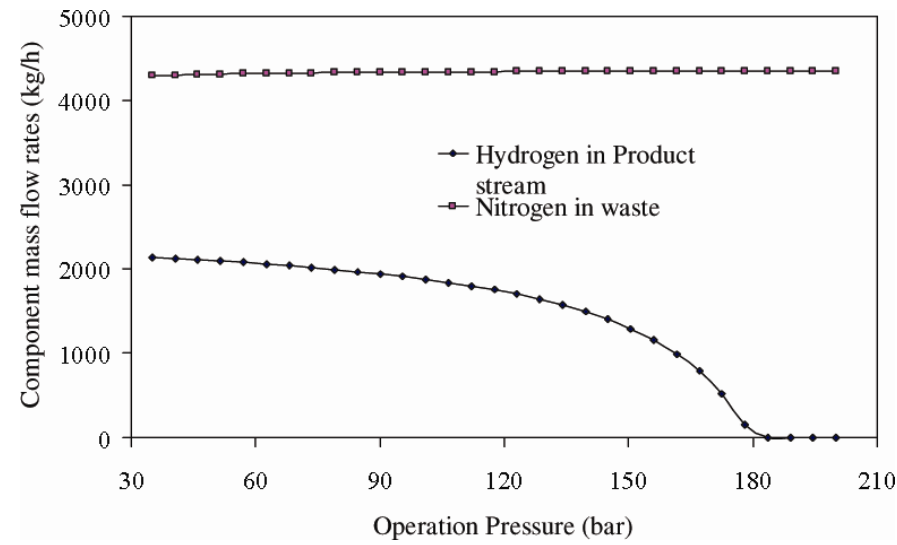

Figure 21 Effect of operating temperature on $\mathrm{H}_{2}$ separation (for the base case 55 bar) (see online version for colours)

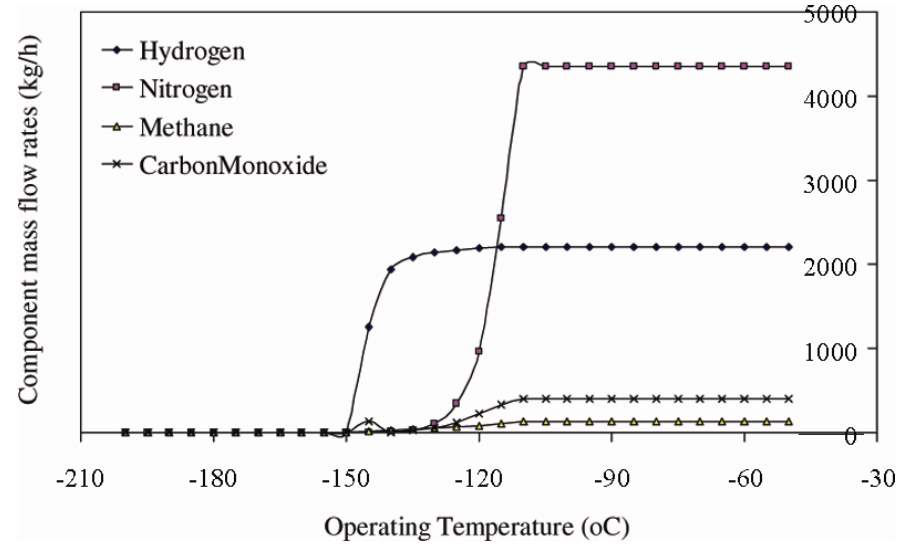




\section{Conclusions}

This study presents the sensitivity analysis of a simulated general, hydrogen generation, ATR process. The results show that it is also possible gain pure $\mathrm{CO}_{2}$ from the reforming process at high amounts to be used in other chemical processes. However, the operating conditions investigated showed that to separate hydrogen from product stream without $\mathrm{CO}_{2}$ removal is also possible and cost effective in some way. Consequently, by the use of several component separators in the subprocess defined other stream components are also possible to be recycled to the main process. Moreover, it is concluded that increasing the capacity of an ATR plant results in extremely high $\mathrm{CO}_{2}$ generation which is environmentally not favourable because of the emissions, considering that most of the $\mathrm{CO}_{2}$ released to the atmosphere is from $\mathrm{NG}$ reforming processes. In addition, $\mathrm{O}_{2} / \mathrm{C}$, $\mathrm{H}_{2} \mathrm{O} / \mathrm{C}$ ratios, reforming temperature are important parameters for an ATR process.

\section{References}

Baloğlu, H. and Nasun-Saygıl1, G. (2005) 'Process simulation of auto thermal natural gas reforming', Cairo 9th International Conference on Energy and Environment, Cairo-Egypt, March 13-17.

Consonni, S. and Vigano, F. (2005) 'Decarbonized hydrogen and electricity from natural gas', Int. J. Hydrogen Energy, Vol. 30, pp.701-718.

Contadini, J.F., Diniz, C.V., Sperling, D. and Moore, R.M. (2000) 'Hydrogen production plants: emissions and thermal efficiency analysis', Second International Symposium on Technological and Environmental Topics in Transports, pp.26-27, Italy, October.

James, S. (2001) 'Hydrogen generation for PEM fuel cells', Fuel Cell Today, Available at: http://www.fuelcellstoday.com/events/archive/2001-10/Hydrogen-Generation-for-PEM-Fuel.

Lee, S.H.D., Applegate, D.V., Ahmed, S., Calderone, S.G. and Harvey, T.L. (2004) 'Hydrogen from natural gas: part I - auto thermal reforming in an integrated fuel processor', Int. J. Hydrogen Energy, USA.

Lewis, D. and Miller, D.F. (2003) 'Meeting U.S. transportation needs in the hydrogen economy, Argonne national laboratory by the university of Chicago for the U.S. department of energy', Available at: www.hydrogen.anl.gov/-25.03.2004.

Manahan, S.E. (2000) Environmental Chemistry. New York, NY: Lewis Publishers; Boca Raton, FL: CRC Press LLC.

Miller, G.Q. and Stöcker, J. (1989) Selection of a Hydrogen Separation Process, Presented at 1989 NPRA Annual Meeting, San Francisco, CA, March 19-21.

Ogden, J.M. (2001) Review of Small Stationary Reformers for Hydrogen Production, A Report for the International Energy Agency Agreement on the Production and Utilization of Hydrogen Task 16. NJ, USA: IEA/H2/TR-02/002.

Ortiz, A.L., Balasubramanian, B. and Harrison, D.P. (2001) Combining Steam-Methane Reforming, Water-Gas Shift and CO2 Removal in a Single-Step Process for Hydrogen Production, DE-FG02-97ER12208. Louisiana, USA.

Singh, S.P. and Malhotra, A. (2004) 'Hydrogen enrichment scheme for auto thermal reforming', United States Patent Office, No: 6,818,198 B2 dated. 16 November.

Spath, P.L. and Mann, M.K. (2001) Life Cycle Assessment of Hydrogen Production Via Natural Gas Steam Reforming, Technical Report, NREL/TP-570-27637, Colorado, USA.

Whysall, M. and Picioccio, K.W. (1999) Selection and Revamp of Hydrogen Purification Processes, Presented at AlChE Spring Meeting, Houston, Texas, March 13-18. 